\title{
Bir Öğrenciyi Üstün Zekâlı ve Yetenekli Olarak Aday Göstermek İçin Doğru Soruları Sormak: Bir Makine Öğrenmesi Yaklaşımı Araştırma Makalesi/Research Article
}

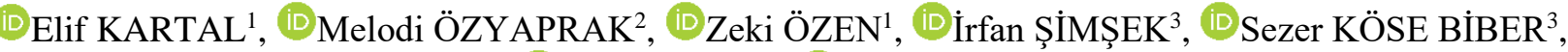 \\ (D)Mahir BİBER ${ }^{4}$, (D) Tuncer $\mathrm{CAN}^{5}$ \\ ${ }^{1}$ Enformatik Bölümü, İstanbul Üniversitesi, İstanbul, Türkiye \\ ${ }^{2}$ Özel Eğitim Bölümü, Hasan Ali Yücel Eğitim Fakültesi, İstanbul Üniversitesi-Cerrahpaşa, İstanbul, Türkiye \\ ${ }^{3}$ Bilgisayar ve Öğretim Teknolojileri Eğitimi Bölümü, Hasan Ali Yücel Eğitim Fakültesi, İstanbul Üniversitesi-Cerrahpaşa, İstanbul, Türkiye \\ ${ }^{4}$ Matematik ve Fen Bilimleri Eğitimi Bölümü, Hasan Ali Yücel Eğitim Fakültesi, İstanbul Üniversitesi-Cerrahpaşa, İstanbul, Türkiye \\ ${ }^{5}$ Yabancı Diller Eğitimi Bölümü, Hasan Ali Yücel Eğitim Fakültesi, İstanbul Üniversitesi-Cerrahpaşa, İstanbul, Türkiye \\ elifk@istanbul.edu.tr, mzyaprak@istanbul.edu.tr, zekiozen@istanbul.edu.tr, irfan@istanbul.edu.tr, sezer@ istanbul.edu.tr, \\ mahir.biber@istanbul.edu.tr, tcan@istanbul.edu.tr \\ (Geliş/Received:12.07.2019; Kabul/Accepted:03.09.2020) \\ DOI: $10.17671 /$ gazibtd. 591158
}

\begin{abstract}
$\ddot{O}_{z e t}-\mathrm{Bu}$ çalışmada, bir öğrencinin üstün zekâlı ve yetenekli olarak aday gösterilmesi için geliştirilen 69 soruluk ölçekten öğretmenin kararında en etkili soruların seçilerek ölçekteki soru sayısının azaltılması amaçlanmıştır. Bu amaçla Nitelik Eleme ve Ki-kare Filtresi nitelik seçimi yöntemleri kullanılmıştır. Ayrıca çalışmada bir öğrenciyi üstün zekâlı ve yetenekli olarak aday göstermede en iyi performansı veren makine öğrenmesi algoritmasının bulunması da hedeflenmiştir. Bunu gerçekleştirebilmek için Rastgele Orman Algoritması, C4.5 Karar Ağacı Algoritması ve Naive Bayes Sınıflandırıcı makine öğrenmesi algoritmaları kullanılmıștır. Analizler sonucunda Ki-kare Filtresi yöntemiyle 69 soruluk ölçek 20 soruya indirilmiş, sonrasında Naive Bayes Sınıflandırıcı bu yeni veri setine uygulandığında, model \%92 doğrulukla bir öğrenciyi üstün zekâlı ve yetenekli olarak aday göstermiştir. Önerilen bu modelin, aday gösterme sürecinde zamandan tasarruf edilmesini sağlayacağı ve ölçeğin öğretmenler tarafından doldurulması esnasında çok sayıda soruyla ilgilenmekten kaynaklı dikkat dağınıklığını önleyerek sonuçların doğruluğunu artıracağı düşünülmektedir. Ayrıca, veriye dayalı öngörü modellerinin aday gösterme sürecinde kullanılmasıyla daha rasyonel kararlar elde edileceğine inanılmaktadır.
\end{abstract}

Anahtar Kelimeler — üstün zekâlı ve yetenekli öğrenciler, nitelik seçimi, makine öğrenmesi, aday gösterme

\section{Asking the Right Questions to Nominate A Student as Gifted and Talented: A Machine Learning Approach}

\begin{abstract}
In this study, it is aimed to reduce the number of questions from a 69-item scale, which is developed to nominate a student as gifted and talented by selecting the most effective questions. For this purpose, Recursive Feature Elimination and Chi-Square Filter feature selection methods are used. Also, it is aimed to find the best performing machine learning algorithm to nominate a student as gifted and talented in this study. To achieve this, analyses are performed with Random Forest Algorithm, C4.5 Decision Tree Algorithm, and Naive Bayes Classifier machine learning algorithms. As a result of the analyses; the 69 -item scale was reduced to 20 questions by using Chi-Square Filter method, and then when Naive Bayes Classifier was applied to this new data set, the model nominated a student with $92 \%$ accuracy as gifted and talented. It is thought that the proposed model will save time in the nomination process and prevent the distraction of attention that can be caused by the high number of questions when teachers fill out the scale. Also, it is believed that more rational decisions will be made in the nomination process by working with data-based prediction models.
\end{abstract}

Keywords — gifted and talented students, feature selection, machine learning, nomination 


\section{INTRODUCTION}

Most of the children are different from each other by having one or more traits and this may cause some advantages and disadvantages in children's educational lives. One of these individual differences is intelligence. Although having higher intelligence than peers is often seen as an advantage, gifted and talented students fall into a disadvantageous position within the education system, because their educational and social-emotional needs are not usually met. Gifted and talented students are disadvantageous regarding the social-emotional aspect due to their asynchronous developments. Researches indicate [1-3] that gifted and talented individuals develop earlier emotionally and socially as well as intellectually. It is common for gifted and talented students starting from early adolescence to prefer the company of adults due to more similar levels of maturity overall. Therefore, it is often difficult for them to socialize. They also have disadvantages in terms of educational needs. First, public schools' curriculum content does not usually match gifted and talented students' interests or abilities. It usually requires gifted and talented students to repeat previously learned material. Also, the learning pace is slow for these students. For all these reasons, gifted and talented students feel unchallenged, usually resulting in a lack of motivation and underachievement [4].

Gagné [5] conceptualized giftedness as high-level skills in particular domains that were blossomed from natural abilities through education. In this regard, giftedness according to him was a result of genetics and the environment. Similarly, Subotnik [6] contended that giftedness was not equal to IQ, it was a dynamic construct instead. She had a developmental concept of giftedness which emphasized the importance of educational experiences, especially in the early grades. Hence, she suggested that gifted and talented children would improve their skills over time and their abilities would transform into expertise and outstanding performance in terms of scholarly productivity, innovation, or artistry.

The main objective of the identification of gifted and talented individuals is the discovery and further development of the individual abilities, potentials, and interests of these individuals [7]. These comprehensive ways of conceptualizing giftedness via talent development models enabled educators to have a broader and more diverse identification process than the traditional psychometric view. So that education can focus on all types of gifted and talented learners' unique needs in the school system instead of labeling and isolating them. In virtue of recent theories of giftedness and current identification processes learning experiences may take into account the abilities, interests, learning styles, and preferred modes of expression of gifted and talented students. These current identification processes apart from standardized tests on cognitive ability, general achievement, and creativity include different approaches which are summarized as follows [8]:
- Teacher observations, including anecdotal reports and informal assessments (a simple anecdote or student writing, an example from problem solving or artistic production, etc.),

- Notification of parents,

- Various checklists and inventories,

- The nomination of the student himself/herself,

- Portfolios,

- Peer nomination,

- Specialized tests (e.g. creative writing, spatial or mechanical ability).

These traditional and alternative assessment tools are seen as a means of leading to an important preliminary identification [8]. Elliott et al. [9] noted that the most common ways of alternative identification for gifted and talented students are classroom teachers and parental observations and rating scales. The nomination is expressed as the first step of the identification process [10]. The identification process of a gifted and talented student in Turkey also begins generally in primary education level by teacher nomination for programs where special education is provided, especially for Science and Art Centers (SACs) which are the most accessible after school programs for gifted and talented learners in Turkey. In SACs, all students receive an education appropriate to their needs and abilities [11]. However, the fact that the nomination process is based on the subjective premise in this way also brought about the questioning of the reliability of the evaluation [12]. The Government of Western Australia Department of Education [12] has stated that subjective opinions should be supported by objective measures. Merrick and Targett [13] emphasized that if the nomination process is not supported by checklists or other similar means but only by the subjective judgment of the teacher, this could result in the inefficient and weak conclusion of the process. A mistake made by the teachers in the process of nomination may deprive students of receiving special education [14].

In this situation, where the process of nomination is so important and critical, teachers must choose the right questions from the questionnaires which embrace current concepts and theories of giftedness. For this reason, this study is aimed to enable teachers to ask the right questions to determine if a student is a candidate for identification. Thus, the authors will be able to determine the most important attributes that affect a teacher's decision to nominate a student for gifted and talented programs. At this stage, the authors benefited from the feature selection methods and this can be seen as one of the contributions of the proposed study. Furthermore, this study is also aimed to find the best performing machine learning algorithm to nominate a student as gifted and talented. To nominate a student as gifted and talented, the classical statistical methods used in the literature and machine learning methods are different. In classical statistical methods, the teacher generally evaluates the student based on a certain threshold value according to the score obtained from the checklist. Machine learning techniques do not use a scoring system or threshold value but make predictions based on 
data. In this study, it is aimed to contribute to the controversial literature on the effectiveness of the teacher nomination of students as gifted and talented candidate. [11, 15-27] with machine learning techniques, different from the classical statistical methods. It is thought that the proposed model will save time in the nomination process and prevent the distraction of attention that can be caused by the high number of questions when teachers fill out the scale. Also, it is believed that more rational decisions will be made in the nomination process by working with databased prediction models. Furthermore, teachers might nominate students more accurately and easily.

\section{LITERATURE REVIEW}

In the early stages of the development of the literature on giftedness and talent, intelligence and ability were treated as two separate concepts, and there was a belief that intelligence was genetic only. And it was enough to be included in the $1 \%$ of the general mental ability of the Stanford-Binet Intelligence Test to qualify as gifted and talented [15]. As time passed by, this view has left its place to a multidimensional concept of intelligence that goes hand in hand with the concept of ability. It became widely accepted that giftedness and talent were multidimensional structures composed of different abilities. The emphasis on the effect of education on the development of intelligence also gained importance and "talent development" concept arises. Meanwhile, the relation between intelligence and academic success was started to be interrogated. The belief that gifted and talented children should be academically successful was perished. Therefore, the concepts of academic giftedness and creative giftedness were emerged [28]. As the field progressed, it became evident that students in special situations such as twice-exceptional students (students who are gifted but also have a special need or disability) or underachievers could be gifted and talented, and the concepts of intelligence and ability began to be addressed in a more comprehensive and flexible manner instead of one dimensional and generally accepted ones. At this point, the differentiation of the identification process began. The belief that recognition and acceptance to certain training programs is unfair and inadequate to be limited to academic achievement or to points scored by standardized intelligence tests has begun to prevail. It was concluded that there could be no excellent identification method that could allow acceptance of all gifted and talented programs and could cover all the dimensions of intelligence at once. Therefore, the emphasis on assessing children with versatile measuring tools has increased [29].

Nomination by teachers is the most widely used form of alternative assessment in the world [30]. Nomination by teachers is an important step in identifying these students. Terman's research on children aged 8-13 years between 1920 and 1945 was the first systematic study on this subject. He benefited from the observations of teachers and families in identifying gifted children and found out that the teachers' observations were far more accurate than the parents' [31]. While worldwide, the nomination by teachers is one of the main components of evaluation scores to seize the opportunity of gifted and talented programs, in Turkey, it is used as a prerequisite for the identification of students who will be directed to the implementation of more standardized diagnostic tools for SACs. In the process of identifying the gifted and talented students who are continuing to SACs, a three-step diagnosis is made: the class teachers nominate the children they consider to be gifted and talented by completing teacher observation forms; a general and collective assessment using the Basic Abilities Test and an individual assessment using the WISC-R (Wechsler Intelligence Scale for Children - Revised) intelligence test. In Turkey, nomination by teachers is not used outside SACs. There is no other teacher nomination scale other than the nomination scale developed for SACs. However, there is a greater need for these scales to diagnose the students better and to meet the students' needs [32].

There are some advantages and disadvantages to using a scale for nomination. This nomination process, called teacher-parent-peer-self rating, gives us much more vivid, experiential, and versatile information about the student. For example, motivation, which is a sign of superior intelligence, can be more informative than standardized tests on criteria such as creativity, leadership, executive functions, or a specific area of interest/ability [33]. In addition to this, no matter how many measurement tools are used to measure gifted and talented students, it is an important factor that it is a human being who will do the assessment and will direct the child to the relevant training program. Therefore, the development of an accurate nomination scale will enhance both reliability and validity in terms of both measurement and evaluation [33], because well-designed scales enable teachers to summarize their perception of students which are derived from a large number of observations [32]. Another important aspect of these scales is their rareness. Using scales for nomination by teachers is one of the few available assessment tools of creativity, leadership, and motivation [34].

Naturally, using a scale for nomination has also some limitations. There are problems such as being subjective in the first place and depending on the level of knowledge and consciousness of the person who is identifying. There are some studies which have shown that the nominations by the teachers do not give very accurate results in determining the talented students and are not adequate on their own [11, 17-23, 15], however, need to be used as a criterion [35-38]. The most important mistakes and shortcomings in the foreground of the inadequacy of nominations by teachers can be listed as follows [10, 39]:

- The failure in separating the successful students and gifted and talented students,

- Insufficient knowledge of the characteristics of gifted and talented children,

- The lack of knowledge on the definition of giftedness and talent,

- The teacher's lack of understanding of the meaning of nomination, 
- $\quad$ Prejudiced behavior towards the socio-economic and demographic infrastructure that the learner has come from,

- $\quad$ Seeing the measurement and evaluation tools used as difficult and burdensome.

It can be said that these deficiencies may apply not only to the nomination by teachers but also to all nomination types. This suggests that it is not sufficient to apply one single criterion in the nomination of gifted and talented students but apply multiple ways in the nomination process [40][42]. Ersoy and Avc1 [43] suggested using an interdisciplinary approach in the identification of a gifted and talented child to provide this diversity in identification. There is extensive research suggesting the use of multiple criteria for identifying gifted and talented students more effectively [44-49]. This means using teacher, peers, and parent nominations in addition to measuring IQ, might be helpful for a broader and valid identification (e.g., Singer, Houtz, and Rosenfield [50]). As a matter of fact, several studies show the effectiveness of teacher nominations of students to enroll in gifted and talented programs during the last few decades [24, 25]. High construct validity and criterion-related validity of teacher judgment instruments for high-ability students have been examined in several studies [26, 34, 51-54].

Regarding these studies, using scales for nomination by teachers can be considered as effective tools to provide valuable information about specific strengths of students, such as generating innovative solutions to problems or having high motivation $[55,56]$. However, it is important to figure out what criteria and characteristics - which are named as rating criteria - offer better scope to identify gifted and talented students, because the rating criteria may be confusing and time consuming for the teachers. Some researches also show that teacher nominations do not always provide very accurate results in identifying talented students and should not be the only evaluation method [11, 15, 17-23]. In these studies, two important variables come to the fore: teacher training and the usefulness of the scale. It is important that teachers are trained professionally to provide more accurate answers to questions on the scale [57]. Also, the developed scales should be consistent with the theories about giftedness and talent, overlap with commonly used scales abroad, and should be statistically valid and reliable. On the other hand, scales should not be too long to distract teachers and cause them to respond incorrectly. Indeed, there are deficiencies in the scales used for SACs in Turkey in respect to validity, content (not including the items of the international scales and all the positive or negative traits relating to different dimensions of the intelligence), and the number of items.

The only known scale that covers different dimensions of the intelligence in Turkey is SAC nomination scale. In the single study on this scale, Sicak [58] investigated the determination strength of the observation form and found a significant relationship between Teacher Observation Form scores and Basic Abilities Test scores, but he also found that the observation form scores had lower ability in explaining the Basic Abilities Test scores. There was no significant relationship between WISC-R test scores and teacher observation form scores. As a result, he concluded that the only known and widely used nomination scale in Turkey hasn't been satisfactory. These seemingly contradictory studies may emphasize the need to obtain more functional, reliable, and valid versions of teacher nominations rather than disregarding nomination by teachers completely. In this context, considering the need for a new and a more comprehensive nomination scale in Turkey, a new and original scale has been developed in this study by using the definition on superior intelligence and ability of The Three-Ring Conception of Giftedness Model theory, the traits of the superior intelligence and ability in the literature, the definition accepted by the Turkish General Directorate of Special Education and Guidance Services [59], and compilation of items from various nomination scales. While developing this scale, unlike the nomination scale used for SACs, the questions that measure different components of the general mental ability, social development and personality traits of the intelligence that the theories and definitions advocated are added. The Three-Ring Conception of Giftedness Model theory defines superior intelligence and ability as advanced, general and special abilities, creativity and high motivation [33]. Therefore, while in the SAC nomination scale there are questions related to only mental and social development and personality traits, items that measure the creative potential and motivation components have been added to the scale developed in the present study. Turkish General Directorate of Special Education and Guidance Services defines the individual with superior intelligence and ability as "learns faster than their peers; has the capacity for creativity, art, and leadership who has special academic ability, can understand abstract ideas, who likes to act independently in the areas of interest and highperforming individual" [59]. Based on this definition, social-emotional development items reflecting the special academic ability and leadership skills have been added to the scale being developed in this study.

Another advantage of the developed scale is that, unlike the ones used in SACs, it is not only positive but also features that emphasize negative but superior intelligence and ability. Examples of these traits, which are compiled from the general gifted and talented student characteristics and items in different scales in the literature, can be given as "bored with repetitions in lessons", "does not obey the instructions", "is cynical". These items were developed on the basis of the features in the six profiles of the gifted children [60]. In this study, it is aimed to select the most effective questions/attributes to nominate a student as gifted and talented from the scale to reduce the number of items that must be taken into account. Also, it is aimed to find the best performing machine learning algorithm to nominate a student as gifted and talented. Thus, teachers might nominate students more accurately and easily.

Machine learning is one of the most popular fields of artificial intelligence, and the underlying thinking is to make the machines self-deciding systems. The term 
"machine" is actually computers, and the aim is "programming computers to optimize a performance criterion using example data or past experience" [61]. In machine learning first, a task (or a problem) such as predicting mortality risk of a patient or type of a tumor (benign/malign), forecasting the weather, estimating the project cost, etc. should be defined. Then data that helps to accomplish the task (or solve the problem) should be given as the experience. There are two main types of learning strategies in machine learning: supervised learning and unsupervised learning. The most important feature distinguishing supervised learning from unsupervised learning is the presence of a target attribute in the data set used. In supervised learning, the data includes both predictive attributes (independent variables) and the target attribute (the dependent variable). For example, in the breast tumor type prediction task; radius, texture, perimeter, area, smoothness, etc. of the tumor can be used as predictive attributes $[62,63]$. The variable, which holds the information if the tumor is benign or malign, is the target attribute. If the target attribute is categorical, the task can be seen as a classification task, otherwise regression. In binary classification, the target attribute has two categories (such as benign/malign). There are various algorithms in terms of learning strategy in machine learning. Naive Bayes Classifier, k-Nearest Neighbor, Decision Trees, Artificial Neural Networks, Support Vector Machines are the most well-known algorithms of supervised learning [64-66]. In a binary classification task, these algorithms require observations from both categories of the target attribute (observations labeled as malign and benign), not only just one of them. In this way, the machine learning algorithm can collect information about observations based on data from both categories, so the machine learning model can predict/estimate observations regardless of category. Data can sometimes consist of too many predictive attributes or researchers aim to find the most important and related ones with the target attribute among them. At that point, before applying the algorithm to the data set, feature selection methods can be used in the data preparation stage. The data set is generally divided into training and test data sets. The training data set is used for the training stage of the algorithm and to create prediction/estimation models. The test data set is used to evaluate the performance of the models or in other words, how much the machine has learned. This is accomplished by using performance evaluation criteria/metrics as Alpaydın [61] is indicated above.

One of the most important advantages of machine learning is once a prediction/estimation model is created, this model can be used to make predictions for the new observations for the related task. The decision-making process can be automated by the model. Furthermore, the model can be integrated into decision support systems, web applications, robots, etc. so end users can easily access it and are easily make predictions/estimations by using the user interface of them without knowing the machine learning process behind. This also indicates that machine learning models can be made cheaper than a human expert. Moreover, machine learning has many advantages of artificial intelligence [67], too. Machine learning models can be easily copied and transferred to another system with an external hard disk, $C D$, etc. Since the model is using the data as an experience like a human and learn to accomplish the task, more rational decisions can be provided, too. Also, unlike a human expert, machine learning models are unlikely to forget and are more permanent.

Since the aims of this study are relevant to the prediction and classification of the data gathered from the scale, supervised learning was used in this study. Two different feature selection methods and three different machine learning algorithms have been used to select the most effective questions/attributes and to find the best performing algorithm to nominate a student as gifted and talented. In this study, it is examined which of the models derived from machine learning techniques using supervised learning gave the closest result to the teachers' decision about the nomination, in other words, which machine learning technique gave the best performance. In the data pre-processing stage of machine learning, the most important attributes in the nomination of a student as gifted and talented were found out of the 69-item scale. In the process, different data sets are created with fewer questions by using feature selection methods and the performances of machine learning algorithms were examined on these data sets.

Today, the use of machine learning techniques, which are used for prediction in many areas such as health, finance, marketing, and sports. Education is also one of the areas where machine learning is used for data analysis and decision-making processes [68]-[70]. In this study, the use of machine learning techniques for the first time as an assessment tool to nominate a student as a gifted student reveals the importance of this study. Another important characteristic of this study is the most effective questions are derived from the 69 -item scale which is prepared to nominate a student as gifted and talented by feature selection methods used in the data pre-processing stage of machine learning.

As a result of this study, it will be possible to nominate a student as gifted and talented with a smaller number of items. Thus, the long implementation time, which is one of the most important problems of using a scale, could be prevented as well as wrong and/or incomplete coding because of boredom and loss of focus [71]. Also, it is believed that more rational decisions will be made in the nomination process with the help of machine learning models. When the relevant literature is examined, no research findings have been found that meet with the aim and the importance of this study. For this reason, the authors believe that this study is the first study that combines machine learning and special education field in terms of the assessment phase to nominate a student as gifted and talented. 


\section{METHOD}

\subsection{Research Model}

In this study survey model, which purposes to describe the current state, is used as a research model to nominate gifted and talented students in different profiles who are yet not identified as gifted and talented with the standardized instruments. An event, an individual or an object, which is the subject of the research, is tried to be defined within its circumstances and as it is in the survey model. No effort is made to change or to influence them in any way. Observing and determining what is wanted to know are the important points [72, 73].

\subsection{The Population and Sample of the Study}

To determine the study sample, the socio-economic status of districts in Istanbul [74] is considered to reach students representing all segments. In accordance with the TUIK data, 3 districts were randomly selected from each of the high, medium, and low socio-economic level groups. As a result of this process, selected districts are Ataşehir, Avcılar, Bayrampaşa, Beşiktaş, Çekmeköy, Fatih, Kadıköy, Sancaktepe, and Zeytinburnu. According to this, the population of the research is composed of the students who are studying in the first, second, third, and fourth grades of the schools in these districts affiliated with the Ministry of National Education. After the determination of all schools in the selected districts [75], two schools from each district were selected randomly. Then, in the selected schools, the number of students to be taken for the research from the 1st through 4th level was determined according to stratified sampling which is one of the probabilistic sampling methods. While deciding the levels of the 60 classes selected, purposive sampling, which is one of the non-probability-based sampling methods, was used because the number of classes at each level was intended to be equal.

To perform binary classification with machine learning algorithms, the data set must include samples of both classes of the target attribute ("gifted and talented" / "nongifted and talented"). For this reason, the teachers were asked to select randomly maximum 5 students who they thought were gifted and 5 who they thought were not gifted. Thus, the sample of the research consists of 400 students. The age of students in the sample ranges from 5 to 10 years. The average age is 8 . There were 166 female $(41,69 \%)$ and 234 male $(58,31 \%)$ students in the study. 106 of these students were enrolled in the first grade $(26,50 \%)$, 86 in the second grade $(21,50 \%), 95$ in the third grade $(23,75 \%)$, and 113 in the fourth grade $(28,25 \%)$.

\subsection{Data Collection Tool}

In this study, a teacher rating scale for gifted and talented students in grades 1-4 was developed which aimed to nominate students for identification. This scale was based on The Three-Ring Conception of Giftedness theory [33], general gifted and talented students features in literature $[49,76,77]$, the definition of giftedness and talent accepted by the Ministry of National Education in Turkey [59] and different profiles of gifted and talented students [78, 60]. In addition, similar checklists $[52,78,79]$ have also been utilized. The Three-Ring Conception of Giftedness Model defines giftedness as advanced general and special abilities, creativity, and high motivation [33]. Therefore, unlike other scales in the field, the current scale includes the creative potential and motivation components. Items referring social-emotional development, special academic ability, and leadership skills were added from the definition of giftedness and talent of the Ministry of National Education. There are items emphasizing favorable characteristics of gifted and talented students like: "Has a number of curiosities and interests", "Has a strong memory", "Creates his/her goals for the future". There are also items emphasizing unfavorable but authentic behaviors of gifted and talented students like: "Does not like repetitive practice", "Does not follow instructions", "Has self-defend against criticism" which were derived from different profiles of gifted and talented students. The scale also comprises information about age, class, and gender. It has 69 items. Instructions were as follows: "How often / to what extent do you observe the characteristics given below in the student you want to nominate or not. Rate the student on a 5-point Likert scale, with 0 as never and 4 as always."

Content validity, construct validity and internal consistency reliability have been examined in the context of validity and reliability studies of the data collection tool in this research. The goals of content validity are to clarify the domain of a concept and judge whether the measure adequately represents the domain [80]. In the current research, a literature review in gifted education was performed by content-area experts to investigate the content validity of the developed scale. 12 items were chosen from the aforementioned nomination scales referring to the most frequently cited characteristics of gifted students and 57 new and original items were written based on the theories aforementioned. Those new items were sent to 20 experts. These experts were 8 university professors who studied in the gifted education field, 5 gifted education specialists, 3 psychologists who specialized in the gifted field, and 4 teachers from different domains. This broad range of professionals from different practical background provided a variety of perspectives so that the key characteristics of students were believed to have enough diversity and comprehensiveness.

A rating form for the experts was developed to provide support for the scale's content validity. The experts indicated how strongly they felt that each item was descriptive of the characteristics via this form. There were 3 categories: 3 (highly appropriate); 2 (appropriate but needs editing or clarification); 1 (not important/exclude). The items which could only receive mean strength ratings of 2 or above from the $80 \%$ of the raters were used in the data collecting process. Following this content validation, the questionnaire was taken to 60 teachers from various 
schools mentioned above. And teachers were asked to rate students on each characteristic based on how frequently they exhibited evidence of the characteristic on a 5-point Likert scale from never to always. Before the application, a brief information meeting was held with teachers on the data collection tool.

Discriminant analysis was performed using the IBM SPSS Statistics 22 to support the construct validity of the developed scale. Discriminant analysis is a multiple regression technique that seeks to find the best linear combination(s) of predictor variables that maximizes the differences among two or more groups [81]. The 69-item scale correctly classified gifted and non-gifted participants in the study. The results on the scale scores suggest that gifted and non-gifted participants differ significantly [Wilks' lambda $=0,962 ; \mathrm{F}(1,452)=17,84 ; \mathrm{p}<0,05]$. The cross-validated classification showed that overall $89,4 \%$ of original group cases were correctly classified.

Cronbach's alpha internal consistency reliability estimates were also calculated. Measures involving attitude are expected to have internal consistency estimates greater than 0,70 [82]. Cronbach's alpha is " 0,967 ", which indicates a high level of internal consistency for the scale.

\subsection{Data Analyses}

Data analyses are performed according to the steps of the CRoss-Industry Standard Process for Data Mining (CRISP-DM). The steps of CRISP-DM are briefly described below [83]-[85]:

\subsubsection{Problem Understanding}

This first phase focuses on a concept designed to understand the goals and requirements of the work being undertaken and to achieve the objectives. All the details regarding the motivation of this study and the background of the problem are given in the introduction and literature review sections.

\subsubsection{Data Understanding}

The data understanding phase includes activities such as collecting data and understanding the data structure. In this study, the column that holds information about whether the teacher will nominate the student as a gifted and talented student is determined as the target attribute for machine learning algorithms in the data set (Table 1). The rest of the 69 questions are used as predictive attributes (Table 1). When the target attribute "giftedCandidate" is examined, it can be seen that a total of 236 students (59\%) of 400 students are nominated as gifted and talented student candidates by their teachers. Supervised learning algorithms which are used for binary classification require observations from two categories of the target attribute ("giftedCandidate") to build a prediction model. Therefore, the data belongs to both "gifted and talented" and "nongifted and talented" candidates were collected from teachers. The abbreviations, descriptions, and data types used in the analyses of the attributes in the data set are listed in Table 1.

Table 1. Attributes of the initial data set

\begin{tabular}{|c|c|c|c|}
\hline & Abbreviation & Description & Data Type \\
\hline \multirow{4}{*}{$\begin{array}{c}\quad 69 \\
\text { Predictive } \\
\text { attributes }\end{array}$} & Age & Student's age & Numeric \\
\hline & Class & Student's class & Nominal \\
\hline & Gender & \begin{tabular}{|c|}
$\begin{array}{c}\text { Student's } \\
\text { gender }\end{array}$ \\
\end{tabular} & Binary \\
\hline & $\begin{array}{c}\mathrm{O} 1, \mathrm{O} 2, \ldots \\
\mathrm{O} 65, \mathrm{O} 66\end{array}$ & $\begin{array}{c}\text { The student } \\
\text { characteristics }\end{array}$ & $\begin{array}{l}\text { O33 binary, } \\
\text { others 5-point } \\
\text { Likert scale }\end{array}$ \\
\hline $\begin{array}{l}\text { Target } \\
\text { attribute }\end{array}$ & giftedCandidate & $\begin{array}{c}\text { Teacher's } \\
\text { opinion on } \\
\text { whether the } \\
\text { student will be } \\
\text { nominated as } \\
\text { gifted and } \\
\text { talented }\end{array}$ & Binary \\
\hline \multicolumn{4}{|c|}{ Total number of attributes: 70} \\
\hline
\end{tabular}

\subsubsection{Data Preparation}

The data preparation phase consists of processes such as data cleaning, removing duplicates, feature selection, and data normalization if necessary.

In this study, the data set initially consists of 420 observations (rows) and 70 attributes (columns). As the study sample is planned to be selected from among the students who are studying in the first, second, third and fourth grades of the schools affiliated with the Ministry of National Education and not identified as gifted and talented, in the first step, 14 observations who were stated as identified by official institutions/had a report as brilliant/gifted and talented were extracted from the data set.

It has been decided to implement missing data imputation to eliminate the effect of the not available (NA) values to the analyses. During missing data imputation, preserving the logical integrity of the data set is considered. The missing values of the numerical attribute "Age" were filled by considering the class of the students because it is thought that students who are in the same class, are almost at the same age. The average age of the 1st, 2nd, 3rd, and 4th-grade class students are assigned to the students in the related classes if the age values are not available.

All attributes except "Age" are categorical. When the missing values of these attributes are completed, the class values of the target values (1: Gifted Candidate, 2: Not Gifted Candidate) in the data set are considered. According to this, missing values of the categorical predictive attributes are completed with the most frequently repeated value of it by considering the class values of the target attribute ("giftedCandidate"). After performing the missing value imputation in the data set, duplicate rows are examined in the data set. As a result, 6 duplicate 
observations were removed from the data set. Thus, a total of 400 observations remained in the data set before the analyses.

Feature selection is performed just before the modeling stage. Feature selection methods provide advantages such as visualizing data and facilitating understanding of the data, reducing the measurement and storage requirements, reducing training and access times, enhancing the predictive performance of machine learning algorithms by eliminating multidimensionality in the data pre-processing step of machine learning [86]. In this study, these advantages are used to select the most effective questions (predictive attributes) from the scale and to reduce the number of questions needed to nominate a student as gifted and talented. Two different feature selection techniques are used in this study.

Recursive Feature Elimination: Recursive Feature Elimination is based on the process of extracting the attributes of the analyzed input that are sorted at each step of the analysis to determine the feature that has the least effect on the decision and performing the analysis with the remaining features. This method can work with algorithms used in machine learning such as Linear Regression, Random Forest, Naive Bayes Classifier. In this study, recursive feature elimination was carried out with the help of random forest [87, 88]. 10-fold cross-validation was used as a performance evaluation method. Finally, the data set (Data set 1) which is obtained with the best performing attribute combination is used in the modeling stage.

Chi-Square Filter: According to the Chi-Square Filter method [89], Cramer's V coefficient [90] is calculated for each attribute in the analyses. This value can be ordered by considering it as a weight value for the attributes. Since there is a single numerical variable "Age" among the attributes in the data set, the importance level of the Age attribute is not calculated and reported as zero. An optimum set of attributes can be generated for a given cutoff point. In this study, since there are no pre-defined cutoff points in the literature and the determination of the cutoff point is based on the preference of researchers, two cutoff points that are selected based on weights (the relationship between each predictive attribute and the target attribute). According to these cutoff points, two different data sets (Data set 2 in which weights are above $70 \%$, Data set 3 in which weights are above 60\%) are created and used in the modeling stage.

\subsubsection{Modeling}

At this stage, the models that are appropriate to the solution and the nature of the problem are selected. By finding the best parameters of the algorithms to be used in the model, experiments are made to give the best result. The summary of machine learning analyses is given in Figure 1.

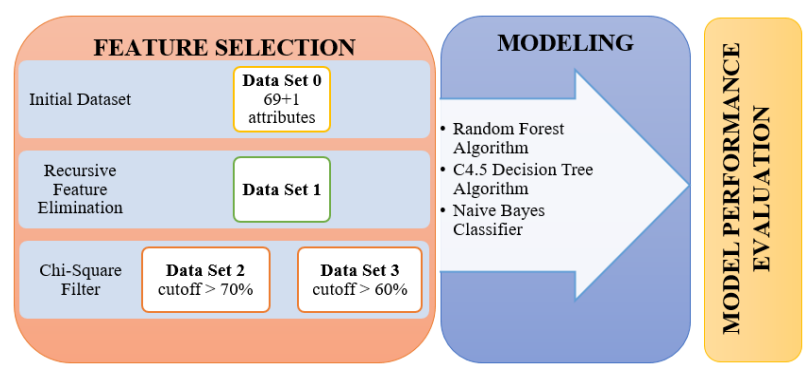

Figure 1. The summary of machine learning analyses in this study

Since one of the aims in this study to reduce the number of items that must be considered to nominate a student as gifted and talented from the scale, three more data sets (Data set 1, Data set 2 and Data set 3) are created. Data set 1, Data set 2 and Data set 3 have different numbers of attributes (number of items that must be considered) and their attribute/item counts are less than the initial data set (Data set 0). This situation has prepared the basis for calculating the performance of machine learning algorithms to nominate a student as gifted and talented on different data sets (Data set 1, Data set 2, and Data set 3) with a different number of items/attributes but less than the initial data set and comparing the performance results obtained in the first case.

In this study, Random Forest Algorithm (RF), C4.5 Decision Tree Algorithm (C4.5) and Naive Bayes Classifier (NB) were applied on three different data sets (Data set 1, Data set 2, and Data set 3 ) obtained from the data preparation stage with the initial data set (Data set 0 ). Thus, the most effective data set, and the best performing algorithm has been revealed to nominate a student as gifted and talented. Random Forest Algorithm, C4.5 Decision Tree Algorithm, and Naive Bayes Classifier are chosen for the following reasons:

- They are one of the most popular algorithms among the "Ensemble Algorithms", "Decision Tree Algorithms", and "Bayesian Algorithms" in machine learning, respectively [91].

- They are supervised learning algorithms [92] and appropriate for binary classification.

- They can work with both categorical and numeric attributes together [83, 93, 94].

The machine learning algorithms used in this study are also briefly summarized below:

Random Forest Algorithm [95]: The working principle is based on the simple but effective "divide and conquer" principle. According to this, small data parts are created. A randomized tree predictor is constructed on every small part obtained. This is followed by aggregating these predictors.

C4.5 Decision Tree Algorithm [96, 97]: It is the enhanced version of the ID3 algorithm using the decision tree model. This algorithm can work with numerical and missing 
values. Branching is performed from the root to the leaves. The most distinctive feature in the data set is taken as the root of the tree. The highest gain ratio is preferred for branching. Subsequently, gain ratio values of the samples are recalculated and the sub-decision tree is constructed.

Naive Bayes Classifier [98]: Naive Bayes, a probabilistic classifier based on the Bayesian theory, assumes independence between predictive attributes. These assumptions rarely apply to real-world problems and are therefore called Naive. Naive Bayes memorizes how each training attribute is related to the outcome and then makes predictions by multiplying the effects of each attribute [99]. However, this method has been successfully applied to many real-world applications.

\subsubsection{Evaluation}

The machine learning model applied to the data set during the process evaluation phase is evaluated extensively. Performance comparison is made between models. The results are visualized and made more meaningful if possible.

In this study, all analyses were performed using the $\mathrm{R}$ programming language [100] and RStudio [101]. The following $\mathrm{R}$ packages were used for the analyses: caret [87], e1071 [102], FSelector [89], ggplot2 [103], randomForest [104], rJava [105], RWeka [106, 107], xlsx [108].

In machine learning, there are some methods and measures to evaluate the performance of the models. Because using the same data set to fit and evaluate the model causes very optimistic performance results [109]. Therefore, in this study as a model performance evaluation method, stratified Hold-out has been preferred. $70 \%$ of the data sets were used for training and $30 \%$ were used for the test phase. This split ratio is the most common construction procedure for Hold-out method [110]. Also, accuracy, error, sensitivity, specificity, positive predictive value, negative predictive value, and F1 score are calculated to compare the model performances. These performance evaluation metrics are briefly explained below $[83,111]$ :

- Accuracy shows the ratio of correct classifications to all classifications (1-Error).

- Error shows the ratio of misclassifications to all classifications (1-Accuracy).

- Sensitivity is the ratio of correct classifications of positive labeled observations to all actual positive labeled observations.

- Specificity is the ratio of correct classifications of negative labelled observations to all actual negative labeled observations.

- Positive Predictive Value (PPV) is the ratio of correct classifications of positive labeled observations to all positive labeled classifications.
- Negative Predictive Value (NPV) is the ratio of correct classifications of negative labelled observations to all negative labeled classifications.

- $\quad$ F1 Score is the harmonic mean of the sensitivity and positive predictive value.

It is important to note that higher accuracy, sensitivity, specificity, positive predictive values, negative predictive values, F1 scores, and lower error are preferred for the performance results.

\subsubsection{Deployment}

The creation of the model does not mean that the project is over. The results of the created model can be understood and interpreted easily, and the model is put into practice.

\section{FINDINGS}

This section covers findings that are obtained from feature selection and model performance evaluation of machine learning techniques. In Figure 3 and Table 7 the attributes are listed from high to low according to their impact on the decision.

\subsection{Findings Obtained from Feature Selection Methods}

According to Recursive Feature Elimination results, the best performance to nominate a student as gifted and talented is obtained with 22 predictive attributes selected from 69. In the beginning, the accuracy value of 0,927 obtained in the analysis performed with the initial data set (Data set 0) which has all 69 predictive attributes increased to 0,932 in the analysis performed with 22 predictive attributes. For this reason, Data set 1 with 22 predictive attributes have been created for use in the modeling step.

The accuracy values obtained from the analyses performed from 1 to 69 by creating different combinations of attributes with the Recursive Feature Elimination method are presented in the form of a line graph in Figure 2. Only the first 15 attribute combinations giving the best accuracy results are given in Figure 2 due to the quality of the graph get worse and becomes incomprehensible as the number of attributes increases.

According to Chi-Square Filter results, the highest score of importance (weight) is 0,798 that belongs to question $\mathrm{O} 38$ and the lowest score is 0,070 that belongs to question 057 . The top five attributes of $\mathrm{O} 38, \mathrm{O} 2, \mathrm{O} 6, \mathrm{O} 4$, and $\mathrm{O} 28$ were highest; O57, O39, Gender, O52, and O60 are the last five attributes with the lowest importance. According to given cut-off points; Data set 2 with 20 predictive attributes and Data set 3 with 34 predictive attributes have been created for use in the modeling step in the range of importance $[0,709 ; 0,798]$ and $[0,615 ; 0,798]$, respectively. 


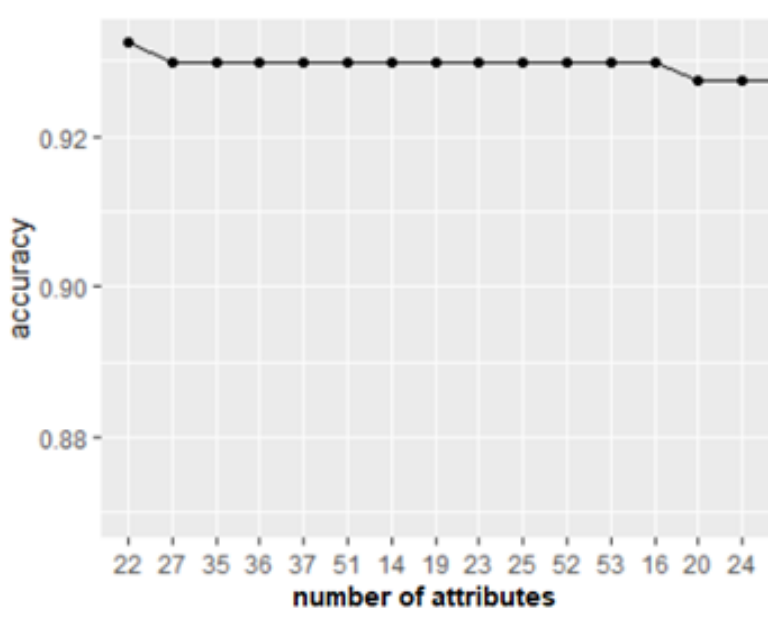

Figure 2. Accuracy values according to the number of variables after the Recursive Feature Elimination method

Besides, the results obtained by the Chi-Square Filter method show that "displaying behaviors that disrupt the classroom order" (O57), "being rated as serious and/or boring by their classmates" (O39), "gender", "being stressful or anxious" (O52), "ridiculing their classmates" (O60) are the least effective factors to nominate a student as gifted and talented.

Figure 3 shows the top five attributes that were found to be most effective to nominate gifted and talented students obtained from the two feature selection methods. These methods produced almost the same results. While $\mathrm{O} 2, \mathrm{O} 4$, O6, and O38 were suggested by both methods, only $\mathrm{O} 46$ and $\mathrm{O} 28$ differed.

Recursive Feature Elimination
- O38: Asking high-level
questions.
- O4: High productivity of ideas.
- O2: Having unique ideas
compared to their peers.
- O6: Perceiving the topics faster
than the friends.
- O46: Standing behind the truth
or values that they believe.

Chi-Square Filter
- O38: Asking high-level
questions.
- O2: Having unique ideas
compared to their peers.
- O6: Perceiving the topics faster
than the friends.
- O4: High productivity of ideas.
O28: Having stronger memory.

Figure 3. The first five attributes, which are listed from high to low according to their impact on the decision, proposed by the feature selection methods

Table 2 shows the final data sets obtained at the end of the feature selection stage.

Table 2. Data sets and attribute counts

\begin{tabular}{|c|c|c|}
\hline Data set & Feature selection method & $\begin{array}{c}\text { Predictive } \\
\text { attribute } \\
\text { count }\end{array}$ \\
\hline Data set 0 & Initial Data Set & 69 \\
\hline Data set 1 & Recursive Feature Elimination & 22 \\
\hline Data set 2 & Chi-Square Filter & 20 \\
\hline Data set 3 & Chi-Square Filter & 34 \\
\hline
\end{tabular}

\subsection{Findings Obtained from Machine Learning Algorithms}

Table 3 can be reviewed for overall performance evaluation results. In Table 3, the analyses are ordered from the best performing to the worst, from the largest to the smallest, respectively, considering the accuracy, error, and F1 score values. Accuracy indicates the proportion of the gifted and talented candidates and non-gifted and talented candidates that are correctly detected by the algorithm among all students. Error is incorrect predictions of the algorithm (1 - accuracy). F1 score is the harmonic mean of the sensitivity and positive predictive value which are given in Table 6 .

According to Table 3, the best performance evaluation measures were calculated (Accuracy $=0,933$, Error $=$ 0,067, and F1 Score $=0,943$ ) with Naive Bayes Classifier by using Data set $1(22+1$ questions) and the performance results are nearly the same with the following five results. Also, on Data set 2 which has only 20 questions/predictive attributes for decision, Naive Bayes Classifier performs nearly the same with the previous results (Accuracy = 0,924, Error $=0,076$, and F1 Score $=0,936$ ). At this point, Naive Bayes Classifier with Data set 2 (is based on ChiSquare Filter method and consists only 20 questions/predictive attributes) can be preferred to nominate a student as gifted and talented instead of using models with more questions such as Random Forest Algorithm with Data set 0 , Data set 1 , and Data set 3 . It is noteworthy that almost all the analyses results are above $90 \%$ accuracy.

Table 3. Performance evaluation in terms of accuracy, error and F1 score (RF: Random Forest Algorithm, NB:

Naive Bayes Classifier, C45: C4.5 Decision Tree

\begin{tabular}{|c|c|c|c|c|c|}
\hline Data set & Algorithm & $\begin{array}{c}\text { Attribute } \\
\text { count }\end{array}$ & Accuracy & Error & F1 score \\
\hline Data set 1 & NB & $22+1$ & 0,933 & 0,067 & 0,943 \\
\hline Data set 3 & RF & $34+1$ & 0,924 & 0,076 & 0,938 \\
\hline Data set 1 & RF & $22+1$ & 0,924 & 0,076 & 0,938 \\
\hline Data set 0 & RF & $69+1$ & 0,924 & 0,076 & 0,938 \\
\hline Data set 2 & NB & $20+1$ & 0,924 & 0,076 & 0,936 \\
\hline Data set 0 & NB & $69+1$ & 0,924 & 0,076 & 0,935 \\
\hline Data set 3 & NB & $34+1$ & 0,916 & 0,084 & 0,927 \\
\hline Data set 2 & RF & $20+1$ & 0,908 & 0,092 & 0,924 \\
\hline Data set 0 & C45 & $69+1$ & 0,840 & 0,160 & 0,865 \\
\hline Data set 1 & C45 & $22+1$ & 0,840 & 0,160 & 0,859 \\
\hline Data set 3 & C45 & $34+1$ & 0,840 & 0,160 & 0,857 \\
\hline Data set 2 & C45 & $20+1$ & 0,798 & 0,202 & 0,818 \\
\hline
\end{tabular}

When the average accuracy, error, and F1 score is examined, machine learning algorithms can be ordered as Naive Bayes Classifier (NB), Random Forest Algorithm (RF), and C4.5 Decision Tree Algorithm (C4.5) (Table 4). 
Table 4. Average accuracy evaluation in terms of machine learning algorithms (RF: Random Forest Algorithm, NB: Naive Bayes Classifier, C45: C4.5 Decision Tree Algorithm)

\begin{tabular}{|c|c|c|c|}
\hline Algorithm & Average accuracy & $\begin{array}{c}\text { Average } \\
\text { error }\end{array}$ & $\begin{array}{c}\text { Average } \\
\text { F1 score }\end{array}$ \\
\hline NB & 0,924 & 0,076 & 0,935 \\
\hline RF & 0,920 & 0,080 & 0,934 \\
\hline C45 & 0,830 & 0,170 & 0,850 \\
\hline
\end{tabular}

According to the number of questions used in order to be able to nominate a student as gifted and talented, then the average of the performance evaluation measures shows that the best performance is obtained with the Recursive Feature Elimination (on Data set 1) (Table 5).

Table 5. Average accuracy evaluation in terms of data sets

\begin{tabular}{|c|c|c|c|c|}
\hline Data set & $\begin{array}{c}\text { Attribute } \\
\text { count }\end{array}$ & $\begin{array}{c}\text { Average } \\
\text { accuracy }\end{array}$ & $\begin{array}{c}\text { Average } \\
\text { error }\end{array}$ & $\begin{array}{c}\text { Average } \\
\text { F1 score }\end{array}$ \\
\hline Data set 1 & $22+1$ & 0,899 & 0,101 & 0,913 \\
\hline Data set 3 & $34+1$ & 0,894 & 0,106 & 0,908 \\
\hline Data set 0 & $69+1$ & 0,896 & 0,104 & 0,913 \\
\hline Data set 2 & $20+1$ & 0,877 & 0,123 & 0,893 \\
\hline
\end{tabular}

Sensitivity, specificity, positive, and negative predictive values of the analyses are shown in Table 6. According to these analyses, using Data Set 2 with Naive Bayes Classifier is suggested to nominate a student as gifted and talented considering the number of questions. The results of the analyses of the proposed Data Set 2 with Naive Bayes Classifier are described below:

- Sensitivity $(94,3 \%)$ indicates the proportion of the "gifted and talented candidates" that are correctly classified (or predicted) by the algorithm among the students who are actually nominated as gifted and talented.

- $\quad$ Specificity $(89,8 \%)$ shows the proportion of the "nongifted and talented candidates" that are correctly classified by the algorithm among the students who are actually not nominated as gifted and talented.

- $\quad$ Positive Predictive Value (PPV) $(93,0 \%)$ indicates the proportion of the "gifted and talented candidates" that are correctly classified by the algorithm among the students who are classified as gifted and talented by the algorithm.

- $\quad$ Negative Predictive Value (NPV) $(91,7 \%)$ shows the proportion of the "non-gifted and talented candidates" that are correctly classified by the algorithm among the students who are classified as non-gifted and talented by the algorithm.

The questions given in Table 7 belong to Naive Bayes Classifier model on the Data set 2 that consists of only 20 questions that were generated by using the Chi-Square Filter method where the best performance was obtained in order to nominate a student as gifted and talented. Table 7 shows the abbreviation and description of these 20 attributes in the scale. The attributes are listed from high to low according to their impact on the decision.

Table 6. Performance evaluation in terms of sensitivity (Sens.), specificity (Spec.), positive predictive value (PPV) and negative predictive value (NPV)

\begin{tabular}{|c|c|c|c|c|c|c|}
\hline Data set & Algorithm & $\begin{array}{c}\text { Attribute } \\
\text { count }\end{array}$ & Sens. & Spec. & PPV & NPV \\
\hline Data set 1 & NB & $22+1$ & 0,943 & 0,918 & 0,943 & 0,918 \\
\hline Data set 3 & RF & $34+1$ & 0,971 & 0,857 & 0,907 & 0,954 \\
\hline Data set 1 & RF & $22+1$ & 0,971 & 0,857 & 0,907 & 0,954 \\
\hline Data set 0 & RF & $69+1$ & 0,971 & 0,857 & 0,907 & 0,954 \\
\hline Data set 2 & NB & $20+1$ & 0,943 & 0,898 & 0,930 & 0,917 \\
\hline Data set 0 & NB & $69+1$ & 0,929 & 0,918 & 0,942 & 0,900 \\
\hline Data set 3 & NB & $34+1$ & 0,914 & 0,918 & 0,941 & 0,882 \\
\hline Data set 2 & RF & $20+1$ & 0,957 & 0,837 & 0,893 & 0,932 \\
\hline Data set 0 & C45 & $69+1$ & 0,871 & 0,796 & 0,859 & 0,812 \\
\hline Data set 1 & C45 & $22+1$ & 0,829 & 0,857 & 0,892 & 0,778 \\
\hline Data set 3 & C45 & $34+1$ & 0,814 & 0,878 & 0,905 & 0,768 \\
\hline Data set 2 & C45 & $20+1$ & 0,771 & 0,837 & 0,871 & 0,719 \\
\hline RF: Random Forest Algorithm, NB: Naive Bayes Classifier, C45: C4.5 \\
Decision Tree Algorithm)
\end{tabular}

Decision Tree Algorithm)

Table 7. Abbreviation and description of the selected 20 attributes (Attr.) from the nomination scale

\begin{tabular}{|c|c|}
\hline Attr. & Description \\
\hline O38 & Asking high-level questions. \\
\hline O2 & Having unique ideas compared to his/her peers. \\
\hline O6 & $\begin{array}{c}\text { Perceiving the topics in the lessons faster than } \\
\text { his/her peers. }\end{array}$ \\
\hline O28 & High productivity of ideas. \\
\hline O5 & Heaving stronger memory. \\
\hline O3 & Interpreting developing events differently. \\
\hline O1 & Solving the problems with different ways. \\
\hline O26 & Thinking on concepts and generalizations. \\
\hline O29 & Having a developed time concept. \\
\hline O36 & Questioning the logic behind the rules. \\
\hline O23 & Having high goals for the future. \\
\hline O17 & Giving justification of ideas. \\
\hline O43 & Determining own goals about future. \\
\hline O9 & Having richness in curiosity and interest. \\
\hline O46 & Standing behind the truth or values that they believe. \\
\hline O34 & Having higher readiness towards some topics in the \\
lessons compared to his/her peers.
\end{tabular}

The Cronbach's alpha internal consistency reliability estimate was also calculated for the 20-item scale. Cronbach's alpha is 0,987 which indicates a high level of internal consistency for our scale with this specific sample. Also, discriminant analysis was performed for the scale. The 20-item scale scores of gifted participants also significantly differ from the scores of non-gifted participants [Wilks' lambda $=0,964 ; \mathrm{F}(1,452)=16,68$; $\mathrm{p}<0,05]$. The cross-validated classification showed that overall $89,4 \%$ of original group cases were correctly classified. 


\section{DISCUSSION AND CONCLUSIONS}

In this study, a teacher rating scale for nominating gifted and talented students was developed by the researchers. The first version of the scale had 69 items. The items of the scale were reduced to 20 items by using machine learning techniques.

It was aimed to determine which criteria are the most influential to nominate gifted students by doing this because which features are associated with superiority more and which features are perceived by teachers to be associated with superiority [59] has always been an important topic in the gifted and talented literature. As a matter of fact, analyses show that in order to be able to nominate a student as gifted and talented, 22 questions can be used with approximately 93\% accuracy, 34 questions can be used with approximately $92 \%$ accuracy (Table 3 ). However, Naive Bayes Classifier performs nearly the same with the above-mentioned results with approximately $92 \%$ accuracy (Table 3 ). It is obvious to conclude that there is not a big difference between the performances of these models. Thus, this study suggests the use of only 20 of these questions among 69. It is thought that this will save time in the nomination process and will prevent the distraction that can be caused by the high number of questions when teachers fill out the scale. In this way, as mentioned in the literature $[11,15,17,23]$, it is aimed to prevent bias and measurement errors caused by teachers in the nomination process for teachers perceiving the evaluation tools as difficult and burdensome [10, 39].

As a result of the model performance evaluation stage, the model created with Naive Bayes Classifier by using ChiSquare Filter method (Accuracy $=0,924$, Error $=0,076$, F1 Score $=0,936)$ were selected as the best model. According to this model, 20 attributes which were listed in the study findings (Table 7), were found to be the most effective attributes in the nomination process. These 20 attributes are consistent with the characteristics of the gifted and talented students found in the literature [112]. In choosing the best model, it has also been a consideration measure to ensure that decisions are made taking into account the minimum number of attributes to save time and to prevent the distraction that can be caused by the high number of questions [10, 39]. Among the 20 attributes that were suggested; "asking high-level questions" (O38), "having unique ideas compared to their peers" (O2), "perceiving the topics in the lessons faster than their peers" (O6), and "high productivity of ideas" (O4) are found as the most effective features determined by both Recursive Feature Elimination and Chi-Square Filter feature selection methods (Figure 3). "Asking high-level questions" (O38), "having unique ideas compared to their peers" (O2) and "high productivity of ideas" (O4) items reflect creativity, and "perceiving the topics in the lessons faster than their peers" (O6) items reflect academic success. The reason why these items are the most effective may be that teachers consider creative thinking and high-level academic achievement as an important distinguishing element of superior intelligence and ability [17, 23, 59].
On the other hand, the results obtained by the Chi-Square Filter method show that "displaying behaviors that disrupt the classroom order" (O57), "being rated as serious and/or boring by their classmates" (O39), "being stressful or anxious" (O52), "ridiculing their classmates" (O60) which are not included in the 20 suggested attributes - are the least effective factors to nominate a student as gifted and talented. Most of the gifted and talented students possess these characteristics according to Neihart and Betts [113]. So, these least suggested items were expected to be effective to discriminate gifted and talented students by the researchers. However, machine learning results did not meet with the researchers' expectations. This result may be attributed to teachers' inaccurate prejudices about the characteristics of gifted and talented people, and to their false prejudices that they should always have favorable characteristics $[11,15,17,23]$ as it was mentioned in the literature. The results suggest that the teachers who filled out the checklists, questionnaires, or scales did not have enough information on the social-emotional traits of the gifted and talented students as they had on their cognitive traits which were stated repeatedly throughout the literature $[35,114,115]$. It is possible to take this case as a limitation of the 69-item scale. In fact, these questions were eliminated by machine learning on a 20-item scale. However, since it is a wrong perspective to match all the favorable features and academic achievement with the superior intelligence and ability [116], these results also show us that teachers need urgent training that includes comprehensive and new developments in superior intelligence and ability.

The best performing machine learning algorithm to nominate a student as gifted and talented is found as Naive Bayes Classifier with the highest average of accuracy $(0,924)$, the highest average F1 score $(0,935)$, and the lowest average error $(0,076)$ (Table 4$)$. Data set 1 , which consists of 22 predictive attributes/questions and the target attribute, was obtained based on the Recursive Feature Elimination method has the highest average of accuracy $(0,899)$, the highest average F1 score $(0,913)$ and the lowest average error $(0,101)$ among all data sets. In future studies, models with higher performance (high accuracy, sensitivity, specificity, etc.) can be obtained by using different machine learning techniques and feature selection methods.

In this study, different from the classical statistical methods used in the literature to nominate a student as gifted and talented, models that learn from the data with machine learning techniques and make predictions based on data have been developed. It is believed that the use of three different machine learning algorithms, namely Random Forest Algorithm, C4.5 Decision Tree Algorithm, and Naive Bayes Classifier, will lead to a wider variety in the studies performed on the identification process of gifted and talented students. For further investigation, the current study may be replicated for only gifted and talented students who will be identified via a standardized IQ test and/or other teacher nomination scales in the field. Furthermore, it was found that two different feature 
selection methods, namely Recursive Feature Elimination and Chi-Square Filter, were performed successfully to decrease the number of questions to nominate a student as gifted and talented. In future studies, researchers may use these methods to eliminate questions that are collected from different scales, questionnaires, forms, etc. Many studies in the field of education [117] until today have used attributes of gifted and talented students as a method to predict high scores on secondary school grade exams [118], to predict the academic performance of undergraduate and graduate students [119], and to find out the impact of the independent variables on prediction if a student will drop out [120]. It is believed that this study which aimed to find the most effective questions/attributes of nominating gifted and talented students with machine learning, will provide similar benefits to the other studies in the literature.

\section{ACKNOWLEDGEMENT}

This study was supported by Scientific Research Projects Coordination Unit of Istanbul University. Project numbers 23538 and 26087. This study was carried out by Istanbul University-Cerrahpasa HAYEF Learning Center R\&D Unit. http://ogrenmemerkezi.istanbulc.edu.tr

\section{REFERENCES}

[1] K. Eklund, N. Tanner, K. Stoll, L. Anway, "Identifying emotional and behavioral risk among gifted and nongifted children: A multigate, multi-informant approach", Sch. Psychol. Q., 30(2), 197-211, 2015.

[2] C. Fonseca, Emotional Intensity in Gifted Students: Helping Kids Cope With Explosive Feelings, 2nd ed. Waco, TX: Prufrock Press, 2016.

[3] H. Peyre et al., "Emotional, behavioral and social difficulties among high-IQ children during the preschool period: Results of the EDEN mother-child cohort", Personal. Individ. Differ., 94, 366$371,2016$.

[4] W. Vialle, K. B. Rogers, "Gifted, talented or educationally disadvantaged?", in Future directions for inclusive teacher education: An international perspective, C. Forlin, Ed. London: Routledge, 112-120, 2012.

[5] F. Gagné, "Debating giftedness: Pronat vs. antinat", in International handbook on giftedness, L. V. Shavinina, Ed. New York: Springer, 155-198, 2009.

[6] R. F. Subotnik, "Developmental transitions in giftedness and talent: Adolescence into adulthood", in The development of giftedness and talent across the life span, F. D. Horowitz, R. F. Subotnik, and D. J. Matthews, Eds. Washington, DC: American Psychological Association, 155-170, 2009.

[7] K. Anderson, Gifted and talented students: Meeting their needs in New Zealand Schools, Wellington, New Zealand: Learning Media Limited, 2000.

[8] New Brunswick Department of Education, "Gifted and Talented Students A Resource Guide for Teachers”, 2007.
[9] C. Elliott et al., Teaching Students Who Are Gifted and Talented A Handbook for Teachers, Newfoundland and Labrador Department of Education, 2013.

[10] Ş. Şengil Akar, I. Akar, “İlköğretim Okullarında Görev Yapmakta Olan Öğretmenlerin Üstün Yetenek Kavramı Hakkındaki Görüşleri”, Kastamonu Eğitim Derg., 20(2), 423-436, 2012.

[11] İ. Akar, M. Uluman, "Sınıf Öğretmenlerinin Üstün Yetenekli Öğrencileri Doğru Aday Gösterme Durumları”, Üstun Yetenekliler Eğitimi Araştırmaları Derg., 1(3), 199-212, 2013.

[12] The Government of Western Australia Department of Education, Talented and Gifted Students eTAGS, 2010.

[13] C. Merrick, R. Targett, Gifted and talented education: Professional development package for teachers - Module 2, Australia: GERRIC Project-The University of New South Wales, 2004.

[14] G. A. Davis, S. B. Rimm, Education of the gifted and talented, 4th Edition. Boston: Allyn and Bacon, 1998.

[15] L. M. Terman, Genetic studies of genius. Vol. 1, Mental and physical traits of a thousand gifted children, Stanford, CA: Stanford University Press, 1925.

[16] F. C. Worrell, B. A. Schaefer, "Reliability and validity of Learning Behaviors Scale (LBS) scores with academically talented students: A comparative perspective", Gift. Child Q., 48(4), 287-308, 2004.

[17] H. E. Dağlığlu, İlkokul 2.-5. sınıflara devam eden çocuklar arasından üstün yetenekli olanların belirlenmesi, Yayımlanmış uzmanlık tezi, Hacettepe Üniversitesi Sağlık Bilimleri Enstitüsü, Ankara, 1995.

[18] G. H. Gear, "Accuracy of teacher judgment in identifying intellectually gifted children: A review of the literature", Gift. Child Q., 20(4), 478-490, 1976.

[19] M. Gökdere, H. Ş. Ayvacı, "SınıfÖğretmenlerinin Üstün Yetenekli Çocuklar ve Özellikleri ile İlgili Bilgi Seviyelerinin Belirlenmesi”, Ondokuz Mayıs Üniversitesi Eğitim Fakültesi Derg., 18, 17-26, 2004.

[20] R. D. Hoge, L. Cudmore, "The use of teacher-judgment measures in the identification of gifted pupils", Teach. Teach. Educ., 2(2), 181-196, 1986.

[21] J. C. Jacobs, "Effectiveness of teacher and parent identification of gifted children as a function of school level", Psychol. Sch., 8(2), 140-142, 1971.

[22] H. Neber, "Teacher identification of students for gifted programs: Nominations to a summer school for highly-gifted students" Psychol. Sci., 46(3), 348-362, 2004.

[23] J. J. Pedulla, P. W. Airasian, G. F. Madaus, "Do teacher ratings and standardized test results of students yield the same information?", Am. Educ. Res. J., 17(3), 303-307, 1980.

[24] S. L. Hunsaker, V. S. Finley, and E. L. Frank, “An Analysis of Teacher Nominations and Student Performance in Gifted Programs", Gift. Child Q., 41(2), 19-24, 1997.

[25] S. K. Johnsen, "Definitions, models, and characteristics of gifted students", Identifying Gift. Stud. Pract. Guide, 1-22, 2004.

[26] A. S. Fishkin, A. S. Johnson, "Who is creative? Identifying children's creative abilities", Roeper Rev., 21(1), 40-46, 1998. 
[27] G. R. Ryser, K. McConnell, Scales for identifying gifted students, Waco, TX: Prufrock Press, 2004.

[28] S. M. Reis, E. E. Sullivan, "Characteristics of gifted learners: Consistently varied; refreshingly diverse", in Methods and Materials for Teaching the Gifted, 3rd ed., F. A. Karnes and S. M. Bean, Eds. Waco, TX: Prufrock Press, 3-35, 2009.

[29] R. Milgram, E. Hong, "Talent loss in mathematics: Causes and solutions", in Creativity in mathematics and the education of gifted students, R. Leikin, A. Berman, and B. Koichu, Eds. Rotterdam: Sense Publishers, 149-163, 2009.

[30] N. McBride, "Early identification of the gifted and talented students: where do teachers stand?", Gift. Educ. Int., 8(1), 19-22, 1992.

[31] H. E. Dağlıoğlu, S. Suveren, "The Role of Teacher and Family Opinions in Identifying Gifted Kindergarten Children and the Consistence of These Views with Children's Actual Performance", Educ. Sci. Theory Pract., 13(1), 444-453, 2013.

[32] T. Jarosewich, S. I. Pfeiffer, and J. Morris, "Identifying gifted students using teacher rating scales: A review of existing instruments", J. Psychoeduc. Assess., 20(4), 322-336, 2002.

[33] J. S. Renzulli, S. M. Reis, The schoolwide enrichment model: A how-to guide for talent development, 3rd ed. Waco, TX: Prufrock Press, 2014.

[34] F. C. Worrell, B. A. Schaefer, "Reliability and Validity of Learning Behaviors Scale (LBS) Scores with Academically Talented Students: A Comparative Perspective", Gift. Child Q., 48(4), 287 308,2004 .

[35] K. L. Speirs Neumeister, C. M. Adams, R. L. Pierce, J. C. Cassady, F. A. Dixon, "Fourth-grade teachers' perceptions of giftedness: Implications for identifying and serving diverse gifted students", $J$. Educ. Gift., 30(4), 479-499, 2007.

[36] Y. Özsoy, M. Özyürek, S. Eripek, Özel eğitime muhtaç çocuklar: “özel eğitime giriș”, Ankara: Karatepe Yayınları, 1998.

[37] J. S. Renzulli, "Teacher nominations", in Encyclopedia of Giftedness, Creativity, and Talent-Vol 2, B. Kerr, Ed. USA: Sage Publications, 878-880, 2009.

[38] G. D. Schack, A. J. Starko, "Identification of gifted students: An analysis of criteria preferred by preservice teachers, classroom teachers, and teachers of the gifted", J. Educ. Gift., 13(4), 346-363, 1990.

[39] Internet: İ. Akar, Özel Gereksinimli Öğrenciler: Özel Yetenekliler, http://www.tuzyeksav.org.tr/wp-content/uploads/2015/09/akaribrahim-ozel-gereksinimli-ogrenciler-ustun-yetenekliler.-mart2012.pdf, 10.10.2017.

[40] C. M. Callahan, E. M. Miller, "A child-responsive model of giftedness", in Conceptions of Giftedness, 2nd ed., R. J. Sternberg and J. E. Davidson, Eds. UK: Cambridge University Press, 38-51, 2005.

[41] J. F. Feldhusen, "Identification and assessment of talented learners", in Excellence in educating gifted and talented learners, J. Vantassel-Baska, Ed. Denver, CO: Love Publishing Company, 193-210, 1998.

[42] S. K. Johnsen, "Identification", in Encyclopedia of Giftedness, Creativity, and Talent-Vol 2, B. Kerr, Ed. USA: Sage Publications, 439-443, 2009.
[43] Ö. Ersoy, N. Avcı, Üstün zekalı ve üstün yetenekliler, özel gereksinimi olan çocuklar ve eğitimleri, “Özel Eğitim” İstanbul: YAPA Yayın Pazarlama, 2001.

[44] A. Y. Baldwin, "Identification concerns and promises for gifted students of diverse populations", Theory Pract., 44(2), 105-114, 2005 .

[45] D. Y. Ford, "The underrepresentation of minority students in gifted education: Problems and promises in recruitment and retention", $J$. Spec. Educ., 32(1), 4-14, 1998.

[46] C. J. Maker, "Identification of Gifted Minority Students: A National Problem, Needed Changes and a Promising Solution", Gift. Child Q., 40(1), 41-50, 1996.

[47] J. A. Plucker, C. M. Callahan, E. M. Tomchin, "Wherefore Art Thou, Multiple Intelligences? Alternative Assessments for Identifying Talent in Ethnically Diverse and Low Income Students", Gift. Child Q., 40(2), 81-91, 1996.

[48] J. S. Renzulli, S. M. Reis, The schoolwide enrichment model: A how-to guide for educational excellence, 2nd Edition. USA: Creative Learning Press, 1997.

[49] J. VanTassel-Baska, E. F. Brown, "Toward Best Practice: An Analysis of the Efficacy of Curriculum Models in Gifted Education", Gift. Child Q., 51(4), 342-358, 2007.

[50] E. M. Singer, J. C. Houtz, S. Rosenfield, "Teacher-Identified Characteristics of Successful Gifted Students: A Delphi Study", Educ. Res. Q., 15(3), 5-14, 1992.

[51] S. T. Mathew, "A review of the Gifted Evaluation Scale", J. Sch. Psychol., 35(1), 101-104, 1997.

[52] S. B. McCarney, P. D. Anderson, Gifted Education Scale-Second Edition, technical manual, Columbia, MO: Hawthorne Educational Services, 1989

[53] T. Oakland, B. A. Falkenberg, C. Oakland, "Assessment of Leadership in Children, Youth and Adults", Gift. Child Q., 40(3), 138-146, 1996.

[54] G. R. Ryser, K. McConnell, Scales for identifying gifted students, Waco TX Prufrock Press Inc, 2004.

[55] S. N. Elliot, R. T. Busse, F. M. Gresham, "Behavior rating scales: Issues of use and development", Sch. Psychol. Rev., 22(2), 313 321, 1993.

[56] K. Heller, J. F. Feldhusen, Eds., Identifying and Nurturing the Gifted: An International Perspective, Lewiston, NY: Hans Huber Publishers, 1986.

[57] G. Lindsay, D. Muijs, D. Hartas, E. Phillips, The National Academy for Gifted and Talented Youth: Evaluation of The First Talent Search and Summer School, Coventry, UK: CEDAR, University of Warwick, 2002.

[58] A. Sicak, "Üstün Yetenekli Öğrencilerin Aday Gösterme Sürecinde Öğretmen Gözlem Puanlarının TKT 7-11 ve WISC-R Puanlarını Yordayıcılık Gücünün İncelenmesi”, 1(1), 7-12, 2014.

[59] O. Kılıç, T. Bağrıaçık, Eds., Beni Anlayın Özel Yetenekli Çocuğum Var, Ankara: General Directorate of Special Education Guidance and Counseling Services, 2017.

[60] G. T. Betts, M. Neihart, "Profiles of the Gifted and Talented", Gift. Child Q., 32(2), 248-253, 1988. 
[61] E. Alpaydın, Introduction to Machine Learning, Cambridge: MIT Press, 2014.

[62] Internet: W. H. Wolberg, W. N. Street, O. L. Mangasarian, Breast Cancer Wisconsin (Diagnostic) Data Set, https://archive.ics.uci.edu/ml/datasets/Breast+Cancer+Wisconsin +(Diagnostic), 06.07.2019.

[63] D. Dua, C. Graff, UCI Machine Learning Repository. University of California, Irvine, School of Information and Computer Sciences, 2017.

[64] M. Peker, O. Özkaraca, B. Kesimal, "Enerji Tasarruflu Bina Tasarımı İçin Isıtma ve Soğutma Yüklerini Regresyon Tabanlı Makine Öğrenmesi Algoritmaları ile Modelleme", Bilişim Teknol. Derg., 10(4), 2017.

[65] H. Erdal, T. Ş. Yaprakli, "Firma Başarısızlı̆̆g Tahminlemesi: Makine Öğrenmesine Dayalı Bir Uygulama”, Bilişsim Teknol. Derg., 9(1), 2016.

[66] A. Özgür, H. Erdem, "Saldırı Tespit Sistemlerinde Kullanılan Kolay Erişilen Makine Öğrenme Algoritmalarının Karşılaştırılması”, Bilişim Teknol. Derg., 5(2), 2012.

[67] V. V. Nabiyev, Yapay Zekâ, 4th ed. Ankara: Seçkin Yayıncılık San. ve Tic. A.Ş., 2012

[68] S. Kotsiantis, "Educational Data Mining: A Case Study for Predicting Dropout-Prone Students", Int J Knowl Eng Soft Data Paradigm, 1(2), 101-111, 2009.

[69] C. Márquez-Vera, A. Cano, C. Romero, A. Y. M. Noaman, H. M. Fardoun, S. Ventura, "Early dropout prediction using data mining: a case study with high school students", Expert Syst., 33(1), 107124,2016

[70] C. Márquez-Vera, C. Romero, S. Ventura, "Predicting school failure using data mining", 4th International Conference on Educational Data Mining, Eindhoven, The Netherlands, July 6-8, 2011.

[71] S. Botsios, D. Georgiou, N. Safouris, "Contributions to adaptive educational hypermedia systems via on-line learning style estimation", J. Educ. Technol. Soc., 11(2), 2008.

[72] J. W. Creswell, J. D. Creswell, Research design: Qualitative, quantitative, and mixed methods approaches, 5th ed. Los Angeles: Sage publications, 2018.

[73] N. Karasar, Bilimsel Araştırma Yöntemi: Kavramlar-İlkelerTeknikler, Ankara: Nobel Yayın Dağıtım, 2003.

[74] (Turkish Statistical Institute) TUIK, Seçilmiş Göstergelerle İstanbul 2013, Ankara: Türkiye İstatistik Kurumu Matbaası, 2014.

[75] Internet: (Ministry of National Education) MEB, Okullar ve Diğer Kurumlar, http://www.meb.gov.tr/baglantilar/okullar/index.php, 19.03.2019.

[76] S. N. Kaplan, "Layering differentiated curricula for the gifted and talented", in Methods and materials for teaching the gifted, F. Karnes and S. Bean, Eds., 107-136, 2009.

[77] U. Sak, Üstün zekâlılar: Özellikleri tanılanmaları eğitimleri, Ankara: Maya Akademi Yayınevi, 2011.

[78] J. S. Renzulli, L. H. Smith, A. J. White, C. M. Callahan, R. K. Hartman, K. L. Westberg, Scales for rating the behavioral characteristics of superior students. Technical and administration manual, ERIC, 2002.
[79] J. E. Gilliam, B. O. Carpenter, J. R. Christensen, Gifted and Talented Evaluation Scales: A Norm-referenced Procedure for Identifying Gifted and Talented Students: Examiner's Manual, Pro-Ed, 1996

[80] K. A. Bollen, Structural Equations with Latent Variables, New York, NY: John Wiley, 1989.

[81] M. C. Pyryt, "Using discriminant analysis to identify gifted children”, J. Educ. Gift., 9(3), 233-238, 1986.

[82] R. K. Gable, M. B. Wolf, Instrument Development in the Affective Domain: Measuring Attitudes and Values in Corporate and School Settings, 2nd ed. Boston: Kluwer Academic Publishers, 1993

[83] M. E. Balaban, E. Kartal, Veri Madenciliği ve Makine Öğrenmesi Temel Algoritmaları ve R Dili ile Uygulamaları, 2nd ed. Beyoğlu, İstanbul: Çağlayan Kitabevi, 2018

[84] P. González-Aranda, E. Menasalvas, S. Millán, C. Ruiz, J. Segovia, "Towards a methodology for data mining project development: The importance of abstraction", Data Min. Found. Pract., 165178,2008 .

[85] C. Shearer, "The CRISP-DM model: the new blueprint for data mining", J. Data Warehous., 5(4), 13-22, 2000.

[86] I. Guyon, A. Elisseeff, "An introduction to variable and feature selection”, J. Mach. Learn. Res., 3(Mar), 1157-1182, 2003.

[87] M. Kuhn, caret: Classification and Regression Training, 2016

[88] M. Kuhn, The caret Package, 2016.

[89] P. Romanski, L. Kotthoff, FSelector: Selecting Attributes, 2016.

[90] Internet: K. Kleinmann, Example 8.39: calculating Cramer's V, $R$ bloggers, https://www.r-bloggers.com/example-8-39-calculatingcramers-v/, 12.07.2017.

[91] Internet: J. Brownlee, A Tour of Machine Learning Algorithms, Machine Learning Mastery, https://machinelearningmastery.com/a-tour-of-machine-learningalgorithms/, 18.02.2019.

[92] R. Caruana, A. Niculescu-Mizil, "An empirical comparison of supervised learning algorithms", in Proceedings of the 23rd international conference on Machine learning, 161-168, 2006.

[93] Internet: S. Khan, Which algorithm fits best for categorical and continuous independent variables with categorical response in Machine Learning?, https://www.quora.com/Which-algorithmfits-best-for-categorical-and-continuous-independent-variableswith-categorical-response-in-Machine-Learning, 18.02.2019.

[94] Internet: S. Khan, What are the advantages of using a naive Bayes for classification?, https://www.quora.com/What-are-theadvantages-of-using-a-naive-Bayes-for-classification, 18.02.2019.

[95] G. Biau, E. Scornet, “A random forest guided tour”, Test, 25(2), 197-227, 2016

[96] H. Dalkılıç, F. Dalkılıç, "Karar Ağaçları Destekli Vadeli Mevduat Analizi”, Akademik Bilişim 2015, Eskişehir, Türkiye, 2015.

[97] B. Hssina, A. Merbouha, H. Ezzikouri, M. Erritali, "A comparative study of decision tree ID3 and C4. 5", Int. J. Adv. Comput. Sci. Appl. Spec. Issue Adv. Veh. Ad Hoc Netw. Appl. 2014, 4(2), 13-19, 2014. 
[98] L. Torgo, Data Mining with R: Learning with Case Studies, 1 edition. Boca Raton: Chapman and Hall/CRC, 2010.

[99] N. Zumel, J. Mount, J. Porzak, Practical Data Science with R, 1st edition. Shelter Island, NY: Manning, 2014.

[100] Internet: cran.r-project.org, The Comprehensive $\mathrm{R}$ Archive Network, https://cran.r-project.org/, 25.03.2018.

[101] Internet: RStudio, RStudio - Open source and enterprise-ready professional software for R, https://www.rstudio.com/, 25.03.2018.

[102] D. Meyer, E. Dimitriadou, K. Hornik, A. Weingessel, F. Leisch, e1071: Misc Functions of the Department of Statistics, $T U$ Wien., 2015.

[103] H. Wickham, ggplot2: Elegant Graphics for Data Analysis Springer-Verlag New York, 2009.

[104] A. Liaw, M. Wiener, "Classification and Regression by randomForest", $R$ News, 2(3), 18-22, 2002.

[105] S. Urbanek, rJava: Low-Level R to Java Interface. 2016.

[106] K. Hornik, C. Buchta, A. Zeileis, "Open-Source Machine Learning: R Meets Weka”, Comput. Stat., 24(2), 225-232, 2009.

[107] I. H. Witten, E. Frank, Data Mining: Practical machine learning tools and techniques, 2nd ed. San Francisco, CA: Morgan Kaufmann, 2005.

[108] Internet: A. A. Dragulescu, xlsx: Read, write, format Excel 2007 and Excel 97/2000/XP/2003 files, http://CRAN.Rproject.org/package=xlsx, 28.05.2015.

[109] H. Brink, J. W. Richards, M. Fetherolf, Real-world machine learning. Shelter Island, NY: Manning Publications Co., 2017.

[110] S. Ali, K. A. Smith, "On learning algorithm selection for classification”, Appl. Soft Comput., 6(2), 119-138, 2006.
[111] E. Kartal, Z. Özen, "Dengesiz Veri Setlerinde Sınıflandırma", in Mühendislikte Yapay Zekâ ve Uygulamaları, 1st ed., O. Torkul, S. Gülseçen, Y. Uyaroğlu, G. Çağıl, and M. K. Uçar, Eds. Sakarya: Sakarya Üniversitesi Kütüphanesi Yayınevi, 109-131, 2017.

[112] G. A. Davis, D. Siegle, S. B. Rimm, Education of the Gifted and Talented, 7th ed. New York: Pearson, 2017.

[113] M. Neihart, G. Betts, "Revised profiles of the gifted and talented", Recuperado Talent Stimuleren Httptalentstimuleren Nl, 2010.

[114] D. B. McCoach, D. Siegle, "Factors That Differentiate Underachieving Gifted Students from High-Achieving Gifted Students", Gift. Child Q., 47(2), 144-154, 2003.

[115] J. B. Hansen, J. F. Feldhusen, "Comparison of Trained and Untrained Teachers of Gifted Students", Gift. Child Q., 38(3), 115$121,1994$.

[116] J. Plucker, A. Rinn, M. Makel, Eds., From giftedness to gifted education: Reflecting theory in practice, Waco, TX: Prufrock Press, 2017.

[117] A. Acharya, D. Sinha, "Application of feature selection methods in educational data mining”, Int. J. Comput. Appl., 103(2), 34-38, 2014.

[118] M. Ramaswami, R. Bhaskaran, “A CHAID based performance prediction model in educational data mining", ArXiv Prepr. ArXiv10021144, 2010.

[119] N. T. Nghe, P. Janecek, P. Haddawy, “A comparative analysis of techniques for predicting academic performance", Oct. 2007, T2G7-T2G-12.

[120] Z. Kovacic, "Early prediction of student success: Mining students' enrolment data", Proceedings of Informing Science \& IT Education Conference (InSITE), 2010. 